\title{
Institutional reform and technological practice: The case of electricity
}

\author{
Draft version for discussion only \\ 2007
}

\author{
Rolf W. Künneke ${ }^{1}$ \\ Associate Professor \\ Economics of Infrastructures \\ Faculty of Technology Policy and Management \\ Delft University of Technology \\ P.O. Box 5015 \\ 2600 GA Delft \\ The Netherlands \\ 蛋+31 (0) 152787752 (direct) \\ 甶+31 (0) 152782695 (assistant) \\ 冝+31 (0) 152787925 \\ E: r.w.kunneke@tudelft.nl
}




\section{Summary}

This paper proposes a framework for categorising possible interrelations between technological and institutional change and applies this framework to the case of the restructuring of the electricity sector. It is argued that there is a need for coherence between institutions and technological practice, so as to safeguard the satisfactory functioning of electricity infrastructure. The identification of possible incoherences between institutions and technological practice allows for a better understanding of the potential drivers for change and the evolutionary processes of which they may be part. This paper attempts to elaborate the nature of this co-evolution in somewhat more detail, using specific levels of analysis that are exemplified in a four-level model. In the case of the restructuring of the electricity sector, the institutional framework has changed from a public utility-oriented, towards a market-oriented system. However, the technological practice remained unchanged: a system-oriented approach that relies on centralised planning, control and operation. This discrepancy between institutions and technological practice leads to significant frictions in the functioning of the electricity sector, but it also offers opportunities for innovation. In order to make liberalisation a success, it might be necessary to stimulate certain technical developments (i.e distributed generation and intelligent networks).

\section{Key words}

Co-evolution, technological and institutional change, restructuring, electricity sector. 


\section{Introduction}

This paper proposes a framework for categorising the possible interrelations between technological and institutional change. It is argued that there is a need for coherence between institutions and technological practice in order to safeguard the satisfactory functioning of large technical systems like the electricity sector. The identification of possible incoherences between institutions and technological practice allows for a better understanding of the potential drivers for change and the evolutionary processes of which they may be part. The framework is illustrated for the case of the restructuring, or so-called 'liberalisation', of the electricity sector.

The literature demonstrates a growing interest in the nature of the co-evolution of technology and governance. Important contributions in this research field include the works of Dosi (1982), Soete (1985), North (1990), Saviotti (1996), Perez (2002), and Von Tunzelmann (2003). As will be elaborated later in this paper, these authors typically apply a long-term perspective, somewhere between fifty and a hundred years or even more, based on an ex post historical analysis. The significance of these theories for recent restructuring processes like those seen in the electricity sector is not straightforward. The question remains as to whether we are in the dawn of a new technological era and structural economic change, or if this is just a very short-term 'hiccup' that will have no significance in the future. The reform process of the electricity sector provides an interesting case for studying the possible nature of the interrelations between technological and institutional change. 
The restructuring of the electricity sector is commonly referred to as "liberalisation". Certain activities, such as the production and supply of electric power, are exposed to competition; whereas network-related activities, including transport and distribution, are strictly regulated. The expectation was that liberalisation would provide high-powered, market-based incentives that would result in higher economic efficiency. The possible relations of these profound institutional changes with the technological features of this vital infrastructure were not addressed as a potential disturbing matter. Traditionally, the electricity sector was considered to inhibit significant economies of scale, and thus was an activity with characteristics of a natural monopoly. In the late 1970s it became apparent that innovative technologies created opportunities to efficiently produce electricity at significantly lower scales of production, thus making competition in this part of the industry possible. This coincided with the first considerations to liberalise this sector. $^{2}$ In that sense it might be argued that technological change in electricity production was one of the enabling factors for liberalisation. However, the possible interrelations between institutional and technological change were not addressed in the discussion on the restructuring of this sector. Supporters of the deregulation process (or at least the mainstream economists supporting it) believed - and still believe - that introducing market-based trading in the electricity industry would per se create or reinforce the incentives for technological innovation. Thus, the coherence between technology and institutions would be re-established as a consequence of the newly evolving market-driven allocation processes. The issue of incoherence between institutional change and the technological status quo was overlooked, or at least underestimated.

An example of an 'unexpected side effect' might illustrate this. There is reluctance by market parties to invest in large-scale electricity generation plants because of the high financial risks under market conditions. Potential investors might even 
perceive significant regulatory risks for these long-term investments. As a result, the reserve margins of many electricity systems are close to what is considered politically and technically reasonable. It is envisaged that a low reserve margin endangers the reliability of the system and the long-term security of supply. There is also worry with respect to lagging investments in networks. The recent blackouts in the USA and some European countries further deepen these concerns. Hence, the issue of security of supply is high on the political agenda. On the other hand, there are also new opportunities for certain technological developments that can profit from these new conditions. Decentralised power production is a good example. Investments in small-scale power plants are perceived as less risky. Besides, they allow very gradual changes in reaction to changing demand conditions. Typical examples include gas turbines, combined heat and power plants (CHP), wind turbines and some solar energy installations. These investments in innovative electricity production technologies cannot be approached as an isolated phenomenon, as they may have technical implications for the functioning of the entire electricity system. If small-scale electricity production breaks through as a major generation technology, networks will need to be technically equipped to handle this multiple in- and outflow in the network, especially at the low voltage level, and they will need to provide innovative services. These so-called 'intelligent networks' will need to perform elementary tasks that are today mainly controlled at the high voltage level. This would involve a fundamental technical restructuring of the electricity system that was not envisaged at the outset of electricity reform. Because the present regulatory regime is equipped to maintain only the present technology of network governance, institutional changes are required in order to allow for these innovations. In other words, an interrelation between institutional and technological change can be expected. 
The possible evolution of a two-way network structure with a decentralized technical control structure is a recent and actual topic. Examples of large scale research initiatives include the European Smart Grids Technology Platform ${ }^{3}$, the IntelliGrid programme of EPRI in the USA ${ }^{4}$, and the GridWise programme of the US Department of Energy. ${ }^{5}$ The development of such an intelligent electricity system has to be considered as a paradigm shift. It implies fundamental technological and institutional changes, which are barely understood at this moment. ${ }^{6}$ This illustrates that a possible new paradigm of decentralized electricity networks is far form obvious.

The objective of this article is to elaborate the nature of the interrelation between institutional and technological change. Although this framework can be applied to other sectors as well, we demonstrate it here for the case of the electricity sector. Using a normative perspective, we address two aspects of the same problem for this specific case:

- How should technology in the electricity sector evolve so as to be consistent with the given institutional change?

- Or alternatively: How should institutions evolve in order to adapt to the given technological features?

The article is structured as follows. Section 2 presents the case of the electricity sector in more detail. Section 3 reflects on a perspective on institutions as provided by Williamson in a four-level model. This model is used as a point of departure for the framework presented in this article. Section 4 summarises some perspectives on the economics of technological practices. Similar to the Williamson model, four levels of technological practice are elaborated on. Section 5 integrates the approaches to institutions and technological practice and applies them to the case 
of electricity. The interrelations between the levels, as well as between institutions and technological practice, are illustrated. Finally, section 6 summarises the main conclusions, speculates on possible policy implications, and presents some challenges for future research.

\section{The case of electricity}

Prior to liberalisation and the deregulation required for the opening of the energy market that accompanied it, utility firms were typically vertically integrated. Vertical integration means that major functions, vested in units in the electricity value chain, are included in one single organisation. ${ }^{7}$ The most extreme case is shown in the top part of Figure 1, below.

Figure 1: The electricity value chain before and after liberalization (Fens (2005))
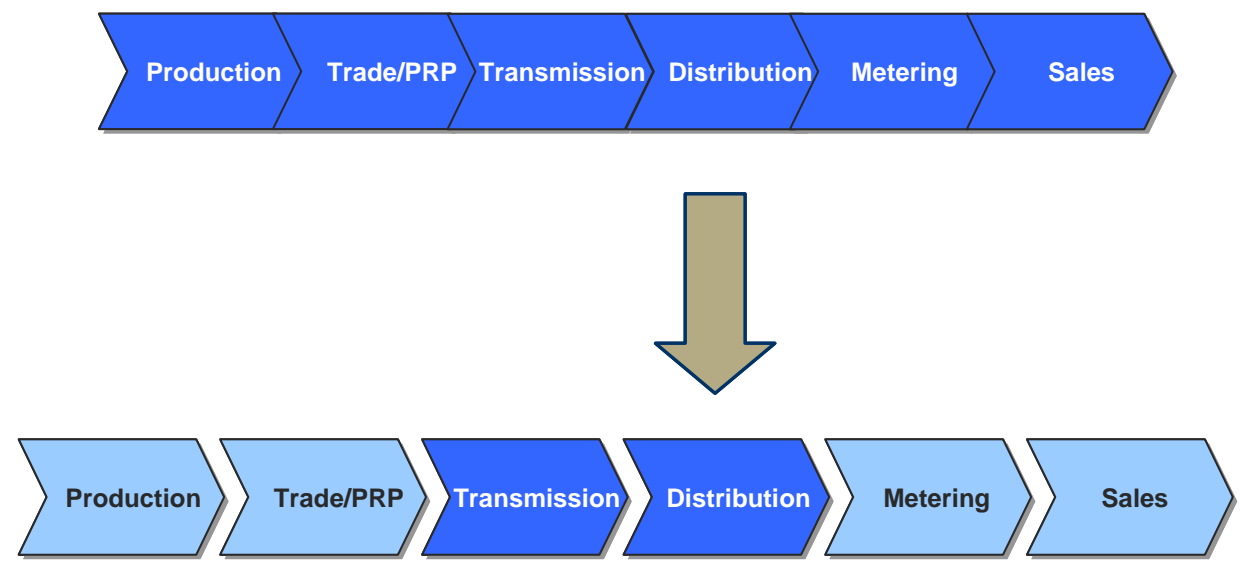

Legend: Light shaded: market-based commercial functions; dark shaded: regulated monopolistic functions

Although there are several opportunities for restructuring the electricity sector, we concentrate in this article on the most extreme case of retail competition, which requires a far-reaching degree of unbundling of the value chain. ${ }^{8}$ As will be demonstrated in this article, this is a very challenging case for uncovering coherence between technology and institutions. 
From an institutional perspective, liberalisation requires the decoupling of major parts of the value chain into independent entities. Since network-related activities are considered natural monopolies, transmission and distribution networks are organised as separate economic entities subject to sector-specific regulation. On the other hand, production, trade, metering and sales are considered to be commercial activities that can be performed under market conditions, independently from each other. It is up to the strategic choices of individual firms and the specific regulatory requirements ${ }^{9}$ as to whether firms specialise in specific activities or integrate different activities within the value chain. From a business perspective, opportunities for realising economies of scale or scope and/or minimising transaction costs are determining factors for positioning in the value chain and for the desired degree of unbundling. Conversely, regulation might prescribe a certain industry structure.

From a technical perspective, there have been some remarkable innovations with respect to the efficient scale of production. Up to the late 1970s, there was a strong emphasis on economies of scale, which resulted in ever-growing plant sizes, up to a size of about 1,000 MW. ${ }^{10}$ Even nowadays such large plants are still constructed, but they are becoming less dominant. There is a tendency towards small-scale plants that are operated close to the consumer base. Well-known examples of this so-called 'decentralised electricity production’ include combined heat and power plants (CHP). These plants produce heat, for example during industrial production processes or for a residential district heating network, while electricity is generated as a joint product. The capacity of these plants is between 50 and 200 MW. But even a much smaller scale is possible. There are some pilot projects of using CHP production within private households. These micro plants have a capacity of only a 
few $\mathrm{kW}$. Figure 2 provides an indication of the increasing economies of scale up to the 1980 s, and the subsequently decreasing economies starting the 1990 s. $^{11}$

Figure 2: Optimal plant size per MW cost curves (1930 - 1990)

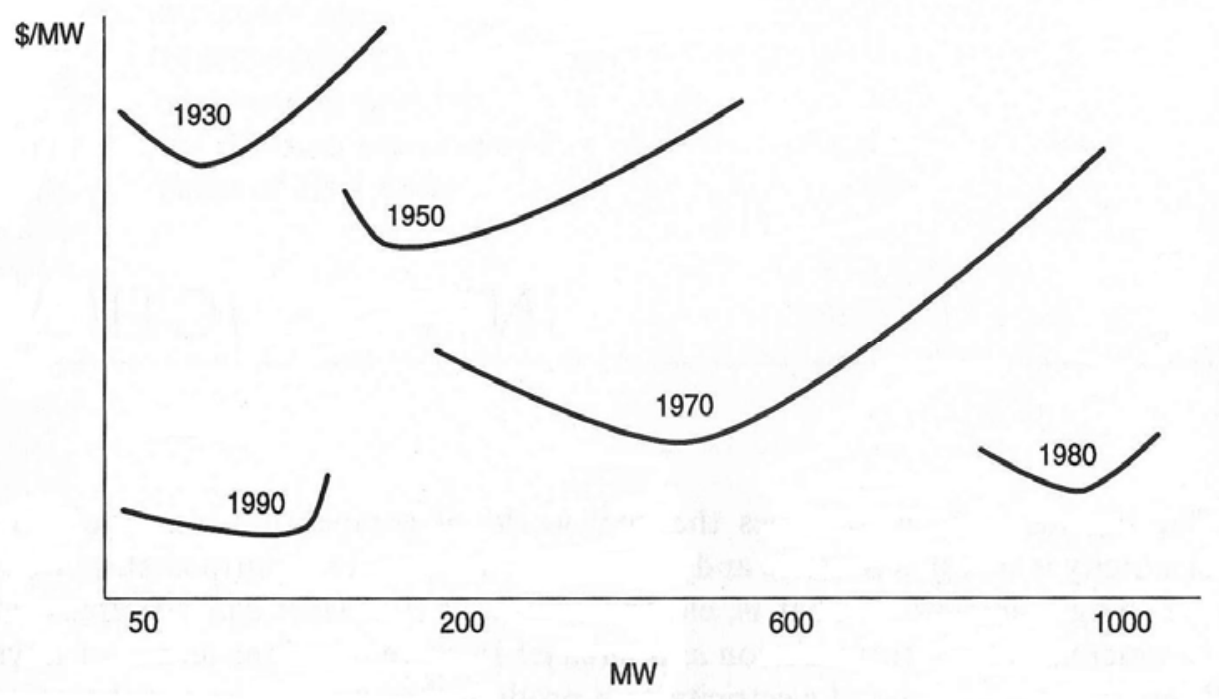

Despite these technological innovations in electricity production, there are no essential changes in the functioning of the electricity system. From a technical point of view, the activities within the value chain are strongly interrelated, before as well as after liberalisation. Nonetheless, small-scale production has only a limited market share. Bulk electricity is generated at centralised production units. It is then traded on the wholesale market and transported via the transmission unit (highways for electricity) and the distribution unit (regional and local networks for electricity). The electricity is metered during transport, not only for billing purposes but also to ensure proper management of the physical flow of electricity in the system. Finally, in the sales unit the physical flow ends with delivery to the end customer according to the contracts agreed upon. Technically, the electricity sector has to be managed as one single integrated system. The flow of electricity cannot be directed between specific economic actors. Rather, it depends on the specific physical circumstances of the electric system as to how and whether 
specific physical transactions are possible. In order to allow a continuous availability of high quality electricity, ${ }^{12}$ all parts of the system, from production to supply, have to be technically balanced at each moment of time. From an economic perspective, this technical system management is a purely collective good that cannot be provided by market allocation.

This results in a very interesting constellation. From an institutional perspective, the electricity value chain seems to evolve towards unbundling and specialisation, whereas technology is based on integrated system planning. This raises the question of whether this is a sustainable situation or whether there is a need for some convergence of technical and institutional governance. As mentioned in the introduction, there are serious signs that the present situation will lead to malfunction of the technical system and adverse economic incentives.

The following sections provide selected economic perspectives on institutional and technological change. This will be helpful in further analysing the possible interrelation between institutional and technological change.

\section{Perspectives on institutions ${ }^{13}$}

Williamson (1998) provides a useful framework for distinguishing different levels of analysis of institutions that is based on different approaches in the field of social sciences. Williamsons framework is based on two main criteria, i.e., the main purpose and the frequency of change of institutions. An important secondary criterion is the level of analysis (Figure 3). Williamson's framework is rather heuristic. Hence, the two main criteria are indicative and aim to highlight only some general differences. In reality it might not always be obvious how to operationalise these criteria. 
Figure 3: The four level model of Williamson (1998)

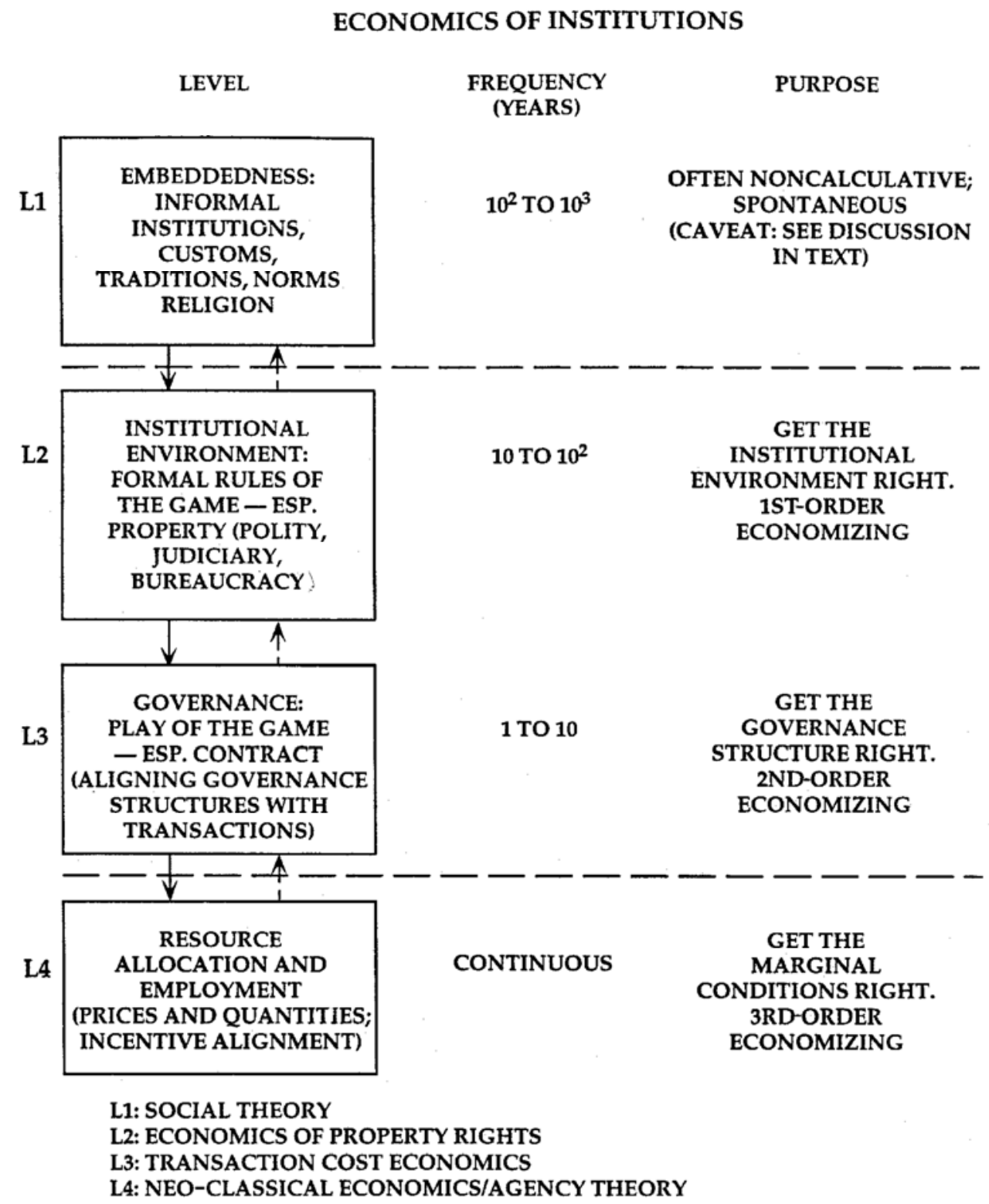

The upper-most level of institutions deals with the social embeddedness of human behaviour, like values, norms, traditions, and customs. Mostly these institutions are informal, and socially and culturally inherited through many generations. Williamson therefore assumes a very low frequency of change, between once in a hundred to once in a thousand years. Williamson points out that religion plays a very important role in this level, and he refers to the work of various economic historians and other social scientists. These values and norms are deeply rooted in society and have a very pervasive influence on social and economic processes. The 
purpose of these embedded social institutions is difficult to explain by rational reasoning, and "deliberate choice of a calculative kind is minimally implicated". They are mostly non-calculative and develop spontaneously. "Be that as it is, the resulting institutions have a lasting grip on the way a society conducts itself. Some societies feel threatened by that and take measures to protect themselves against 'alien values'”. ${ }^{14}$ Understanding these institutions is the domain of anthropology, history and sociology. To this interpretation of Williamson it can be added that the level of analysis is, in a broad sense, the functioning of social systems. In economics, the formation and influence of informal institutions (and the interaction with formal institutions) is often referred to as 'Original Institutional Economics' of which Veblen (1919) and Commons (1934) are two of the founding fathers. ${ }^{15}$ This complex field of research is necessarily quite descriptive by nature.

The second level, the institutional environment, is distinguished by its focus on formal legal arrangements in order to 'get the institutional environment right'. This is the product of intentional political activity to frame the 'rules of the game'. These 'rules of the game' are largely determined by the polity, judiciary and bureaucracy that shape the social and economic activities according to specific objectives. Level 2 refers to the formal institutions that constitute the legal rules: for example, property rights and public organisations like bureaucracies. 'Economics of property rights' theories provide important insights into how formal rules influence economic behaviour. ${ }^{16}$ Their focus is on economic incentives and costs of the enforcement of formal rules. The level of analysis is often the state or government. Williamson argues that there are only very rare windows of opportunity for reforming these formal institutions. A gradual change is difficult to orchestrate because of the many different actors and interests involved, the complex nature of these formal institutions and the accompanying decision-making processes. The development of the European Union might serve as an example in 
this respect. Williamson points to some rare occasions for radical changes: for instance, civil war, occupations (like the Second World War), breakdowns (Soviet Union and Eastern Europe) or a military coup (Chile). Therefore, the frequency of change of these formal institutions is estimated to be between ten and a hundred years.

Taking the formal legal arrangements of Level 2 as given, 'governance structures' or 'the play of the game' is the topic of the third level. The formal arrangements of the second level are relevant to concrete transactions and often need further elaboration and specification. This is associated with transaction costs as a consequence of for instance negotiations, monitoring or legal settlement. This third level is concerned with the actors' perspective of economic allocation. This is the field of "second-order economising", in which the specific governance structures are addressed with respect to markets, hybrids, firms and public bureaus. Organisational and contractual arrangements need to serve the individual objectives of the actors. Transaction costs economics ${ }^{17}$ and the positive agency theory provide typical examples for an institutional analysis on this level. The economic rationales behind various contractual arrangements and organisational structures are explained. ${ }^{18}$ "The period over which such decisions come up for consideration is of the order of a year to a decade". ${ }^{19}$ This is a rough estimation of the typical period in which governance structures such as contracts, concessions, and joint ventures are renewed and/or changed.

Resource allocation and employment of scarce resources is the focal interest of Level 4. The main purpose is to satisfy the marginal conditions for resource allocation in order to accomplish narrowly defined objectives like profit maximisation or the achievement of certain financial or output targets. These problems of resource allocation are often very short-term and have to be 
continuously resolved. A typical level of analysis would be a production plant within a firm. In traditional, mainstream neoclassical economics, actors are assumed to adjust prices and/or output in such a way as to gain maximum profits. More recently, normative agency theory applies to this level of analysis by elaborating efficient incentive structures related to different risk profiles and/or multi-task factors or multi-principal concerns. ${ }^{20}$

This framework is very illustrative and will be used as a starting point to categorise different economic approaches to technological developments. There are some critical remarks that must be addressed. First of all, the differentiating criteria (purpose, frequency and level of analysis) cannot always be clearly operationalised, or even empirically proved, for these different levels. They have to be handled as rough indications that identify different lines of economic analysis. Coming down to the level of details, there is certainly room for argument.

A second and more important point of critique is the lack of a proper analysis of the interrelations between these levels. Williamson acknowledges these interrelations by depicting arrows in his figure, symbolising possible feedbacks between different types of institutions. However, in his 1998 article, he does not further elaborate on the nature of these feedbacks. ${ }^{21}$ In extending this line of reasoning, Groenewegen and Künneke (2005) argue that there might be some kind of 'logic' between the levels of institutions.

This concept of a logic existing between different levels of institutional analysis can be used to distinguish different categories of institutional change: evolutionary changes within a certain logic, and revolutionary institutional changes that results in an entire new institutional structure with a new logic. The recent changes in the electricity sector provide a good example. ${ }^{22}$ Before its liberalisation, the electricity 
sector was perceived in many countries as a public utility. This can be interpreted as a specific form of embeddedness of this sector in the norms of society. Accordingly, the institutional arrangements allowed for public ownership (Level 2) and direct political involvement in the decision process (Level 3). The resource allocation was oriented towards pubic service tasks. In the period after liberalisation, electricity has been increasingly perceived as a commodity. This does not only hold for commercial activities such as electricity production, trade and supply. Under the conditions of price cap regulation, even network companies are stimulated to develop profit-maximising behaviour, while safeguarding essential public service tasks. By regulating the annual price increase and providing certain quality of service standards, the profits of the network operators are basically not restricted. ${ }^{23}$ The more network operators succeed in lowering the costs, the higher the profits for a given price cap and quality standards. Accordingly, firms are privatised (Level 2) and their governance is oriented towards the realisation of private investors' objectives (Level 3). Profit maximisation has become an important goal of resource allocation (Level 4). This example illustrates a shift of the dominant logic from public utility towards a market orientation in which electricity is treated as a commodity. ${ }^{24}$

The identification of a logic in institutional arrangements allows for the identification of drivers for change. Is it possible to identify certain events connected to certain levels that have initiated a restructuring of institutions and possibly the emergence of a new logic ${ }^{25}$ How might this new logic be characterised in terms of possible institutional arrangements? In this article, this concept of logic between institutions is extended to different levels of technological practice. It will be investigated whether there is a certain coherence between institutional arrangements and technological practices. If this is the case, institutional changes, like the liberalisation of the electricity sector, are expected to 
influence technological practice, possibly resulting in technical innovations that allow for a technical decomposition of the value chain.

\section{Perspectives on technological practices}

\subsection{Delineation}

For the purpose of this article, the notion of technological practice refers to the way in which technological artefacts are planned and operated in order to meet human needs. Like Williamson did with his scheme of different levels of institutions, we aim to identify different levels of technological practice, based on the same delineating factors (i.e., purpose and frequency of change). This results in the following impressionistic scheme (Figure 4) that should be interpreted as a heuristic approach to be substantiated for the case of the restructuring of the electricity sector. After introducing the main features, the different levels will be discussed in separate sections, in which also the delineating factors will be further operationalised and specified. 
Figure 4: Four levels of technological practice

\begin{tabular}{|l|l|l|l|}
\hline Level & \multicolumn{1}{|c|}{$\begin{array}{c}\text { Economics of } \\
\text { technological practice }\end{array}$} & \multicolumn{1}{|c|}{$\begin{array}{c}\text { Frequency of } \\
\text { change (years) }\end{array}$} & \multicolumn{1}{|c|}{ Purpose } \\
\hline 2 & Technological paradigm & $>100$ & $\begin{array}{l}\text { Often non-calculative and } \\
\text { spontaneous }\end{array}$ \\
\hline 3 & Technological trajectory & $10-100$ & $\begin{array}{l}\text { First-order economising: } \\
\text { development of coherent } \\
\text { and efficient technological } \\
\text { systems }\end{array}$ \\
\hline 4 & $\begin{array}{l}\text { Operation } \\
\text { management }\end{array}$ & $\begin{array}{l}\text { Second-order economising: } \\
\text { Optimisation }{ }^{26} \text { of individual } \\
\text { technical components }\end{array}$ \\
\hline
\end{tabular}

Part of this scheme is inspired by a heuristic model of technological change developed by Dosi (1982). He introduced the notions of 'technological paradigm’ and 'technological trajectories'. Technological paradigms are defined as “models or patterns of solutions to selected technological problems, based on selected principles based on natural science or selected material technologies” (Dosi (1982), p. 152). A change of a paradigm is often discontinuous and associated with fundamental innovations. 'Technological trajectory' refers to “the pattern of normal problem solving activity ... on the ground of a technological paradigm" (Dosi (1982), p. 152). Although Dosi's model should not be interpreted too deterministically, within the framework of this article it provides some important insights into the nature of technological change. ${ }^{27}$ Changes in the trajectory are generally gradual and continuous of nature. They appear in the course of the further optimisation of a specific technological paradigm in accordance to changing customer needs, newly arising technical opportunities or changing economic 
scarcities and prices. The impact of technological change might also be different. Technological paradigms appear globally throughout the entire community that is associated with a specific technology. Technological trajectories are developed within specific systems in which these paradigms are applied.

The notion of 'routine' is developed by Nelson and Winter (1982). Nelson and Sampat (2001) use this term to refer to "a collection of procedures which, taken together, result in a predictable and specifiable outcome" (Nelson and Sampat (2001), p. 42). Given a specific objective and context, routines focus on specific choices and conditions that have to be served or fulfilled. Referring to our model, routines can be interpreted as a further specification of technological trajectories. Individual firms utilize technological trajectories according to their individual objectives and potentials in order to produce certain outputs that might provide them competitive advantages and thus safeguard its long-term continuity and profitability. Given this more specific focus, routines are assumed to deal primarily with the optimisation of certain elements of a given system. These routines are localised on the $3^{\text {rd }}$ level of our scheme, with an indicative frequency of change between one and ten years and a focus on second-order economising.

Finally, the fourth level is dedicated to day-to-day operation and management, given certain routines, technological trajectories and paradigms. These continuous changes are the field of 'process management'.

The next sections elaborate somewhat more deeply on the specificities of the different levels. 


\subsection{Technological paradigm}

On the most general level of technological development, long-term waves of technological practices can be identified. Examples include the five Kontradiev waves or different industrial revolutions. Typically, these long waves describe different phases of economic development or activity, which are typically associated with certain technological innovations. Often these waves are identified based on patterns of economic growth or prosperity. Technological innovations are introduced as external shift parameters that explain the changing economic activities. Famous examples are the invention of the steam machine, industrial mass production, and the introduction of information technology. Technologies are described, rather than systematically compared. Obviously, there are important differences between the phases of technological development, but what are its constituting factors?

Von Tunzelmann (2003) identifies features of technologies that might be related to economic governance. His focus is on process technologies, which he describes in terms of the key resources to which they are related (labour/capital/information): “motive technologies (steam/electricity/oil), material technologies (iron/steel/silicon), communication technologies (telegraph/telephone/internet), transportation technologies (rail/automobile/aircraft), handling technologies, construction technologies, as well as the succession of technologies more obviously related to production process and to the product" ${ }^{28}$ Figure 5 provides a chronology of three industrial eras and their technological specificities. 
Figure 5: A chronology of industrial eras (Von Tunzelmann (2003))

\begin{tabular}{|c|c|c|c|}
\hline & $\begin{array}{l}\text { First Industrial Revolu- } \\
\text { tion }\end{array}$ & $\begin{array}{l}\text { Second Industrial Revolu- } \\
\text { tion }\end{array}$ & $\begin{array}{l}\text { Third Industrial Revolu- } \\
\text { tion }\end{array}$ \\
\hline Approximate dates & $1750-1815$ & $1870-1914$ & $1973-$ \\
\hline Location & UK & USA, Germany & USA, East Asia \\
\hline Technologies & Machinery & Chemicals & ICT, biotechnology \\
\hline (motive) & Water, steam & Electricity, oil & (Nuclear, renewable) \\
\hline (material) & Iron & Steel, plastics & Silicon, smart materials \\
\hline Automation & of Transformation & of Transfer & of Control \\
\hline Process type & Labour & Capital & Information \\
\hline
\end{tabular}

Perez distinguishes five technological revolutions in the past 200 years and relates some of them to different infrastructures (Figure 6). The frequency of technological change is higher than that in Von Tunzelman's scheme, occurring every 50 to 70 years. But still these phases clearly indicate non-continuous changes that can be perceived as different technological paradigms. The technological revolutions are initiated by a 'big bang of technological revolution', as indicated in the figure. Perez acknowledges that it is difficult to identify appropriate beginning and end dates for each period. She argues that the different phases are not only characterised by some innovative breakthrough technologies, but they also certainly have impact on economic allocation processes. “...It is suggested here that for society to veer strongly in the direction of a new set of technologies, a highly visible 'attractor' needs to appear, symbolizing the whole new potential and capable of sparking the technological and business imagination of a cluster of pioneers. This attractor is not only a technological breakthrough; what makes it so powerful is that it is also cheap or that it makes it clear that business based on the associated innovations will be cost-competitive. That event is defined as the big bang of the revolution.",29 
Figure 6: Five industrial revolutions (Perez (2002))

\begin{tabular}{|c|c|c|c|c|}
\hline $\begin{array}{l}\text { Technological } \\
\text { revolution }\end{array}$ & $\begin{array}{l}\text { Popular name } \\
\text { for the period }\end{array}$ & $\begin{array}{l}\text { Core country or } \\
\text { countries }\end{array}$ & $\begin{array}{l}\text { Big-bang initiating } \\
\text { the revolution }\end{array}$ & Year \\
\hline FIRST & $\begin{array}{l}\text { The 'Industrial } \\
\text { Revolution' }\end{array}$ & Britain & $\begin{array}{l}\text { Arkwright's mill opens } \\
\text { in Cromford }\end{array}$ & 1771 \\
\hline SECOND & $\begin{array}{l}\text { Age of Steam and } \\
\text { Railways }\end{array}$ & $\begin{array}{l}\text { Britain (spread- } \\
\text { ing to Continent } \\
\text { and USA) }\end{array}$ & $\begin{array}{l}\text { Test of the 'Rocket' } \\
\text { steam engine for the } \\
\text { Liverpool-Manchester } \\
\text { railway }\end{array}$ & 1829 \\
\hline THIRD & $\begin{array}{l}\text { Age of Stecl, } \\
\text { Electricily and } \\
\text { Heavy Engineering }\end{array}$ & $\begin{array}{l}\text { USA and } \\
\text { Gcrmany forging } \\
\text { ahcad and } \\
\text { overtiaking } \\
\text { Britain }\end{array}$ & $\begin{array}{l}\text { The Carnegie Bessemer } \\
\text { steel plant opens in } \\
\text { Pittsburgh, Pennsylva- } \\
\text { nia }\end{array}$ & 1875 \\
\hline FOURTH & $\begin{array}{l}\text { Age of Oil, the } \\
\text { Automobile and } \\
\text { Mass Production }\end{array}$ & $\begin{array}{l}\text { USA (with } \\
\text { Germany at first } \\
\text { vying for world } \\
\text { leadership), later } \\
\text { spreading to } \\
\text { Europe }\end{array}$ & $\begin{array}{l}\text { First Model-T comes } \\
\text { out of the Ford plant in } \\
\text { Detroit, Michigan }\end{array}$ & 1908 \\
\hline FIFTH & $\begin{array}{l}\text { Age of Information } \\
\text { and Telecommuni- } \\
\text { cations }\end{array}$ & $\begin{array}{l}\text { USA (spreading } \\
\text { to Europe and } \\
\text { Asia) }\end{array}$ & $\begin{array}{l}\text { The Intel microproces- } \\
\text { sor is announced in } \\
\text { Santa Clara, California }\end{array}$ & 1971 \\
\hline
\end{tabular}

\subsection{Technological trajectory}

Technological trajectories deal with the understanding of the features of specific technical systems that serve certain needs (Dosi 1982). The work of Saviotti (1996) provides interesting theoretical and empirical insights into the evolution of specific technologies. He addresses radical as well as incremental technological evolution (Saviotti (1996), p. 73). Radical evolution might be compared with changing paradigms, whereas incremental evolution is related to technological trajectories.

Saviotti (1996, p.92) discusses the concept of ‘variety’ and relates it to his notions of incremental and radical evolution. In an attempt to make these concepts more concrete and operational, he points to the need of developing criteria for the distinguishability of different technologies. This may be done by a specific set of 
technological and service characteristics, which would then allow measuring the distance between similar approaches. Saviotti admits, however, that this might not be possible in all cases, and that sometimes the distinguishability might also be based on subjective criteria. To him, this does not detract from the value of his approach. He points to the fact that similar problems arise in information science, biology and ecology. The concept of variety has been proven to be useful, even if there are problems with respect to operationalisation and measurability.

Figure 7 provides an illustration of change in variety of transport technologies. It depicts a family tree of the development of the transport technology at a high level of abstraction. The horizontal axis indicates a timeline, whereas the vertical axis denotes different transport technologies that have evolved over time.

Figure 7: Change in variety of transport technologies (Saviotti (1996))

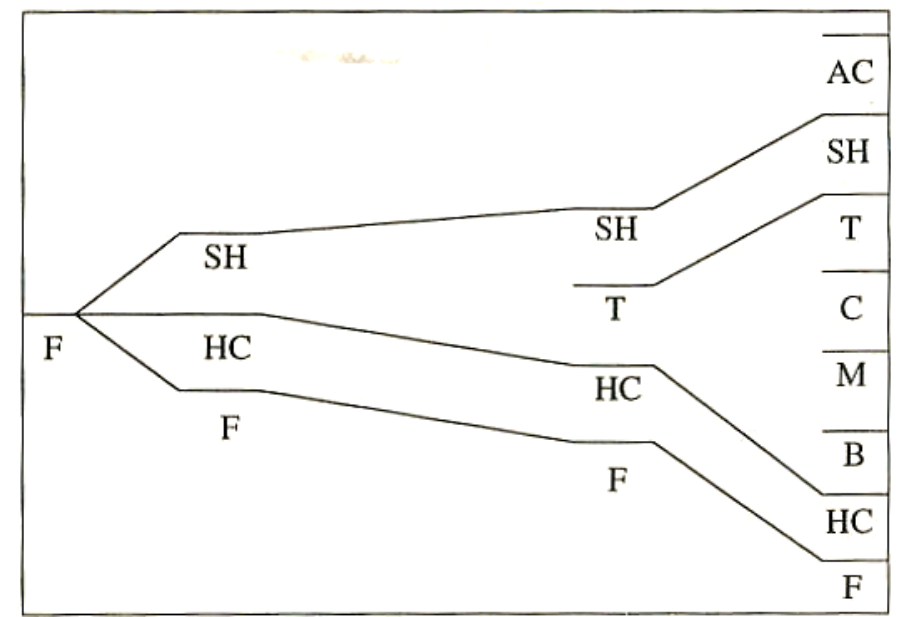

Legend: $A C=$ aircraft SH= ship; $T=$ train; $C=$ car; $M=$ motorcycle; $B=$ bicycle; $H C=$ horse drawn carriage; $F=$ foot

Different cases for changes of the technological trajectory and technological paradigm can be identified in this scheme. ${ }^{30}$ Throughout the entire time period, there is one technological trajectory for foot transportation. All other technologies 
appeared as new paradigms that are further developed in certain trajectories. The beginning of each new path indicates the start of a novel technological paradigm; the path itself depicts the trajectory.

Referring to our four-level model of technological practice, these examples demonstrate that it is empirically possible to materialise and illustrate the difference between technological paradigms and technological trajectories. Besides, it also demonstrates the relevance of the delineating factors of these different levels. The change of technological paradigms occurs only rarely, once in several decades or decennia ${ }^{31}$, whereas significant modifications of the trajectories might appear occasionally, i.e., once or more every ten years. These changes refer to the entire available knowledge with respect to these technologies and can therefore be perceived as changes at the level of technical systems.

\subsection{Technological routines}

Referring to Nelson and Sampat (2001), technological routines are primarily oriented towards the optimisation of scale and scope of production facilities. Given a certain technology, the profit-optimising operation of an installation or a firm is determined and translated into specific routines of operation. This includes traditional long-term cost minimisation issues, like the determination of the Minimum Efficient Scale of a firm, related to various economies of scale and scope that might be achieved for a certain given technology.

Typically, these long-term decisions depend on the lifetime of the physical capital. In the specific case of the electricity sector, this might be up to 50 years for specific appliances such as generation plants. But this is a somewhat atypical situation. For the purpose of our four-level model of technological practice, the frequency of establishing new routines is likely to be between 1 and 10 years. But this should be 
interpreted as an indicative measure. Besides, it can be argued that even for very long-lived applications in the electricity sector, there are opportunities for the modification of important technological characteristics, because existing installations like generation plants can be renovated and modernised.

\subsection{Operation and management}

This fourth level refers to the day-to-day management of production plants or system components. This includes the continuous adjustment of a given plant in reaction to changes of technical or economic parameters. For example, the demand for a certain product might change, or a technical emergency may occur. This operation and management takes account of the traditional economic approaches on short-term cost minimisation.

\subsection{Logic between the levels}

It becomes evident that the four levels of technological practise refer to different levels of abstraction. The first level of technological paradigm refers to the available technological knowledge on how to approach and solve certain technical challenges. The second level of technical trajectories applies this available knowledge to specific systems, like the electricity sector. The third level of routines mainly refers to the level of the firm and second-order economising, i.e., the realisation of economies of scale or scope. Finally, level four (operation and management) deals with the short-term optimisation of plants. Similar to the logic seen between the different levels of institutional arrangements, it can be argued that the four levels of the economics of technological practice can be expected to be arranged according to a certain logic.

Among others, the work of Saviotti illustrates that technological paradigms highly determine the development of specific trajectories, which in turn define the 
essential parameters for the development of routines and of operation and management. Thus, a certain degree of consistency or logic might be expected. On the other hand, it cannot be excluded that in lower levels certain technical restrictions become obvious that challenge trajectories of paradigms at a higher level. Just as for institutions, it is expected that there are some bilateral relations between the different levels. If certain technical restrictions at a lower level become too stringent, this might be an important stimulus to challenge the existing trajectory or even paradigm. ${ }^{32}$ This argument will be further empirically illustrated for the case of electricity in the next section.

\section{The logic between institutions and technological practice: the case of electricity}

In the previous sections, the economics of institutions and technological practice are elaborated in a comparable four-level model. Under the given description we are now able to merge these models (Figure 8).

Figure 8: Four levels of the Economics of Institutions and Technological Practice

\begin{tabular}{|l|l|l|}
\hline Level & Economics of Institutions & Economics of Technological Practice \\
\hline 1 & Embeddedness & Technological paradigm \\
\hline 2 & Institutional environment & Technological trajectory \\
\hline 3 & Governance & Technological routines \\
\hline 4 & $\begin{array}{l}\text { Resource allocation and } \\
\text { employment }\end{array}$ & Technical management and operation \\
\hline
\end{tabular}

Posing this interrelation raises at least three questions, including the following:

- How can these different levels of the Economics of Institutions and Technological Practice be operationalised? 
- What is the nature of possible interrelations between the different levels and the two columns, i.e. the 'logic' of the Economics of Technological Practice and Economics of Institutions?

- How can the co-evolution between institutions and technological practise be understood in the case of electricity sector?

\subsection{Operationalisation of the different levels of Economics of Institutions and Technological Practice}

Each level of the Economics of Technological Practice and the Economics of Institutions will be successively operationalized and empirically illustrated for the case of electricity before and after the liberalisation. The main findings are summarised in Figures 9 and 10.

\section{Technological practice}

The operationalisation of the technological paradigm addresses the question which 'models or patterns of solutions ${ }^{33}$ are applied for the provision of electric energy. In order to apply this very general notion to the electricity sector, we identify the characteristics of the fundamental coordination mechanism that governs the technical coordination of the different components of the electricity infrastructure. ${ }^{34}$ For the last century, the technological paradigm of the electricity sector can be best characterised as oriented towards large-scale operation and centralistic control. The technological practice of this first level strongly builds on the opportunities for technical system optimisation by central dispatch ${ }^{35}$ of the generation units that are connected to the network. Under this paradigm, economics of scale can be realised with an increasing size of the production plants and a growing size of the electricity system, ${ }^{36}$ resulting in natural monopolies. The electricity sector has emerged as an integrated system with very strong technical interdependencies. In order to safeguard the stability of the system, inflow and 
outflow of electricity has to be balanced at each moment of time. This is a quite challenging technical issue, which is complicated by the fact that significant largescale storage is essentially not available.

The second level of technological trajectories deals with the 'pattern of normal problem solving activity $\ldots$ on the ground of a technological paradigm, ${ }^{37}$ For electricity this can be translated in two aspects. First, the degree to which the coordination and control of the networks is centralized. Second, features of the dominant technologies of producing electricity. First, with the growing size of the electricity system, various centres of control have evolved, from a regional towards a national and supranational level. With the availability of ICT, computerised optimisation programmes have emerged that allow for a further automation of system control and dispatch. A second important aspect relates to the production technologies. Traditionally electricity is generated by rotating turbines that are powered by steam, water, or hot gases. This involves various primary energy sources, including coal, natural gas, oil, or uranium. Existing technologies are further refined, for instance, by utilising different primary energy sources (for instance, biomass or off-shore wind), increasing the efficiency of the boilers and turbines, or combining power and heat production. These traditional technologies are typically large-scale, and require centralized modes of production of electric power. However, as already mentioned in section 2, in recent years, new technologies have evolved, such as photovoltaic power production or small-scale combined heat and power installations (chp). These new production technologies often operate on a significant lower scale of production and are more dispersed throughout the electricity infrastructure. Given these characteristics, they allow for a more decentralized technological coordination. Without going into the details of these different technologies, it can be stated that the variety of electricity production trajectories has significantly increased throughout the past century. The 
traditional means of large-scale production fit better to the paradigm of centralized technical coordination and control than the more recent developing trajectories of small-scale production.

Level 3 of technical routines is about the procedures that make the behaviour of the technical system predictable and controllable. In the electricity sector these technical routines include, for example, the development of system optimisation programs that calculated the least cost electricity generation facilities, the so-called 'merit order'. The cooperation between different network operators was improved by defining and implementing technical standards, as well as the conditions of use of the networks, i.e., the network code. ${ }^{38}$ Advanced technical routines also contributed to the improved and more efficient operation and maintenance of plants.

Finally, the day-to-day technical management and operation of the various components of the electricity infrastructure (level 4) is not addressed in this article. In general it can be stated that these activities evolved toward higher technical and economic efficiency along with the new opportunities for automation and computerisation.

Comparing the situation before and after liberalatisation, it appears that there was no significant change with respect to the Economics of Technological Practise. The characteristics of the traditional centralized coordination and control clearly prevail. However, there are some interesting nuances. After liberalisation, there seems to be more room for the development of small-scale production technologies (level 2). As another important difference the operation of electricity plants (level 3) is now very much influenced by economically independently-operating electricity firms. For these competing firms, economic optimisation has priority 
above the technical optimisation of the electricity system. For the electricity system operator, this means that he/she has to facilitate these economic transactions as much as technically possible. Technical optimisation is no longer a dominant system objective. This can be expected to influence the technological regimes and the day-to-day management of the system. Figure 9 summarises the main findings.

Figure 9: Technological Practice of the electricity sector, before and after liberalisation

\begin{tabular}{|c|c|c|c|c|}
\hline & Level & Operationalisation & $\begin{array}{l}\text { Before } \\
\text { liberalisation }\end{array}$ & $\begin{array}{l}\text { After } \\
\text { liberalization }\end{array}$ \\
\hline \multirow{7}{*}{ 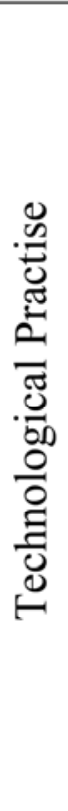 } & $\begin{array}{l}\text { Technological } \\
\text { paradigm }\end{array}$ & $\begin{array}{l}\text { Fundamental coordination } \\
\text { mechanism of the } \\
\text { electricity infrastructure }\end{array}$ & $\begin{array}{r}\text { Large-scale oper } \\
\text { cc }\end{array}$ & $\begin{array}{l}\text { tion and centralistic } \\
\text { ntrol }\end{array}$ \\
\hline & \multirow{3}{*}{$\begin{array}{l}\text { Technological } \\
\text { trajectory }\end{array}$} & $\begin{array}{l}\text { Degree of centralisation of } \\
\text { the coordination and } \\
\text { control of networks }\end{array}$ & $\begin{array}{r}\text { Increasing degree } \\
\text { from regional to na } \\
\text { coordinati }\end{array}$ & $\begin{array}{l}\text { of centralisation, i.e. } \\
\text { ional to supranational } \\
\mathrm{n} \text { and control }\end{array}$ \\
\hline & & \multirow[b]{2}{*}{$\begin{array}{l}\text { Features of dominant } \\
\text { technologies of electricity } \\
\text { production }\end{array}$} & \multicolumn{2}{|c|}{$\begin{array}{l}\text { Large-scale centralised modes of } \\
\text { production. }\end{array}$} \\
\hline & & & & $\begin{array}{l}\text { Development of } \\
\text { small-scale } \\
\text { technologies. }\end{array}$ \\
\hline & & \multirow{2}{*}{$\begin{array}{l}\text { Procedures that make the } \\
\text { behaviour of the technical } \\
\text { system predictable and } \\
\text { controllable }\end{array}$} & \multicolumn{2}{|c|}{$\begin{array}{l}\text { System optimalisation, for example } \\
\text { through technical standards and network } \\
\text { codes. }\end{array}$} \\
\hline & & & & $\begin{array}{l}\text { Economic } \\
\text { optimalisation on a } \\
\text { firm level }\end{array}$ \\
\hline & $\begin{array}{l}\text { Technical } \\
\text { management } \\
\text { and operation }\end{array}$ & $\begin{array}{l}\text { Day-to-day management } \\
\text { and operation }\end{array}$ & \multicolumn{2}{|c|}{ No further specification } \\
\hline
\end{tabular}

\section{Institutional features, before and after liberalisation}

The institutional features before and after liberalisation can be described in two stylised models, i.e., the public utility model and the commodity model. In the preliberalisation period, the electricity sector was often described as a 'public utility', which might be interpreted as an orientation towards a public utility model. In the post-liberalisation period, there is more emphasis on the stimulation of competitive markets, signalling a tendency towards a commodity model. ${ }^{39}$ We will elaborate 
these stylised models in the following Figure 10 as an operationalisation of Williamson's four-level model. These models will be illustrated with some practical examples. It should, however, be emphasised that real world electricity sectors are hybrid and thus will not fit strictly into either category.

Figure 10 is structured as follows. The first column refers to the four levels of the Williamson scheme. The second column operationalises each of these levels for the case of the electricity sector. Accordingly, the subsequent columns specify the two stylised models.

The first level of 'embeddedness' is operationalised by the dominant policy focus that is assumed to reflect the social expectations towards the functioning and performance of the electricity sector. For a long period (from the '20s through the '70s of the past century) the electricity sector belonged to the core of what was called 'public utilities'. These firms were expected to operate according to certain social and political objectives that included the stimulation of economic development, social health and individual welfare. Accordingly, the sector was strongly regulated and politically dominated. This is reflected in the institutional environment (level 2) that is characterised in terms of property rights (i.e., ownership structure) and the sectoral organisation as specified by the regulatory framework. In Europe, this resulted in an institutional environment with public ownership and sector-specific regulation of regional monopolies. In the USA, strictly regulated private ownership prevailed, but there was also a significant share of public ownership. With respect to the governance (level 3), there was a strong national orientation of the sector with an emphasis on political controllability and accountability, not only in publicly owned utilities, but also in private firms. The allocation mechanism (level 4) was characterised by regulated tariffs. 
Figure 10: Institutional features of the electricity sector, before and after liberalisation

\begin{tabular}{|c|c|c|c|c|}
\hline & $\begin{array}{l}\text { Williamson } \\
\text { levels }\end{array}$ & Operationalisation & $\begin{array}{l}\text { Before } \\
\text { liberalisation: } \\
\text { Public utility model }\end{array}$ & $\begin{array}{l}\text { After } \\
\text { liberalisation: } \\
\text { Commodity model }\end{array}$ \\
\hline \multirow{8}{*}{ 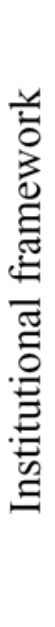 } & Embeddedness & Dominant policy focus & $\begin{array}{l}\text { Public service/ public } \\
\text { value }\end{array}$ & Competition \\
\hline & \multirow{3}{*}{$\begin{array}{l}\text { Institutional } \\
\text { environment }\end{array}$} & Ownershin & Public & Private \\
\hline & & Regulatory framework & Sector specific & Competition policy \\
\hline & & Market structure & Regulated monopoly & Competitive market \\
\hline & \multirow[t]{3}{*}{ Governance } & \multirow[t]{2}{*}{ External governance } & $\begin{array}{l}\text { Emphasis on political } \\
\text { controllability }\end{array}$ & $\begin{array}{l}\text { Emphasis on } \\
\text { economic } \\
\text { profitability }\end{array}$ \\
\hline & & & National orientation & $\begin{array}{l}\text { International } \\
\text { orientation }\end{array}$ \\
\hline & & Internal governance & Political control & $\begin{array}{l}\text { Shareholders } \\
\text { control }\end{array}$ \\
\hline & $\begin{array}{l}\text { Resource } \\
\text { allocation }\end{array}$ & Allocation mechanism & Regulated tariffs & $\begin{array}{l}\text { Competitive market } \\
\text { prices }\end{array}$ \\
\hline
\end{tabular}

After liberalisation, the institutional features have tended more towards the commodity model. The policy focus (level 1) is oriented towards enabling competition in this sector, hence electricity is treated like any other traditional economic good. The market is expected to perform in such a way that social needs are best served. Accordingly, the institutional environment (level 2) is characterised by private ownership of energy firms, competitive market structures and a regulatory framework that is oriented towards competition policy.

The governance (level 3) of private firms is oriented towards economic profitability in a globalising economy. Shareholders' control is an important aspect of the internal governance. Competitive market prices are the resource allocation mechanism (level 4). Under these circumstances, energy firms will develop new contractual relationships with their buyers and suppliers. In an attempt to realize competitive advantages, customers might be offered new contracts with additional services and various pricing schemes. In the contractual relations with suppliers there might be more emphasis on lower costs of important inputs. Accordingly, the 
routines of the energy firms will also adapt to the incentives provided by the institutional framework of the commodity model. For instance, cost effective trading of energy is becoming much more a core issue of the business, as well as differentiated approaches to different market segments.

\subsection{The 'logic' of the Economics of Technological Practice and the Economics of Institutions}

The public utility model seems to establish equilibrium between institutions and technological practice. This characterises the situation prior to liberalisation. Before liberalisation, there was a long period of time without major drivers for fundamental technological or institutional change. Given the public service orientation, the institutional structure of the sector was very much centralised as the technological practice. The electricity industry was perceived and governed as a single system, for which, among other things, investment plans and prices were determined for the entire system. The performance of the system, i.e., serving certain social objectives, was the most important output criterion. The firms were highly vertically integrated, as depicted in the upper value chain of Figure 1. Production, supply and network services were technically and economically strongly interrelated by ownership rights, contracts, and / or regulation.

In this pre-liberalisation period, institutional organisation very much followed the technical necessities. The existing technology depended strongly on a centralised institutional approach of planning and control. Thus, the technological practice determined the institutional framework. The technological paradigm of a unified system approach fits very well with the public service orientation that defined the institutional embeddedness. The strong technical interrelations reflected the vertical integration of firms. Public ownership was a very good means to stimulate 
cooperation between the different actors and to treat the system performance as the overarching sector performance. Regulated tariffs served as resource allocation mechanisms, reflecting the political preferences with respect to the public service tasks.

Comparing the commodity model of the liberalised electricity market with the unchanged technological practice results into a completely different picture. In order to allow for competition, networks had to be unbundled from production, supply and other commercial activities. Networks are still perceived as natural monopolies that have to function under a strictly regulated regime. Also with respect to the commercial activities, a process of specialisation and reorientation of firms began. This resulted in a strong fragmentation of the value chain (Figure 1). Within these different parts of the value chain, actors started to behave as independent market-oriented firms. This is in line with the commodity model. However, the technical reality is still very different. In a technical sense the electricity sector is still an integrated system with significant interrelations between the activities of firms involved in it. This causes positive and negative external effects as well as public goods characteristics of services that are not properly priced and allocated under market conditions. As a result, there are remarkable market failures, and the technical functioning of the system could be endangered by the individualistic behaviour of certain firms. Examples of market failures include the missing incentives to invest in systems security of supply and the longterm development of sustainable energy sources. ${ }^{40}$ Technological failures became evident in some of the recent blackouts in various countries. ${ }^{41}$

The task of a system operator who safeguards the technical stability of the system is very fundamental in liberalised electricity markets. This system operator validates whether the economic transactions are technically feasible and contribute 
to the stability of the system. In case of instability or emergency, the system operator can directly intervene in order to safeguard the supply of electricity. This function is very much oriented towards the day-to-day management of the electricity system at the lowest level of the scheme.

Under the conditions of a liberalised market, actors are typically not concerned with the capabilities or capacity of the electricity system. For example, the network is often treated as a 'copper plate' that should allow all kinds of economic transactions without any technical restrictions. This is, of course, a hypothesis, which in reality does not hold. Long-term security of supply is another typical issue on the system level, for which individual firms in a liberalised market do not share significant economic incentives. Furthermore, reliability is an important issue. Investments in peak capacity are essential for system reliability when, under rare circumstances, a very high electricity demand has to be satisfied.

On the other hand, also the institutional framework of the commodity model poses new demands on the technical system. An example illustrates this case. Under market conditions, there is a tendency towards product differentiation. Customers have different preferences with respect to the delivery of electricity, which translates into different levels of willingness to pay. For electricity suppliers, this offers opportunities to create new market opportunities. Some clients might, for example, be satisfied with a somewhat lower reliability, whereas others just demand a very reliable supply. The price for the first group of customers might be lower than for the second. Under the current technical conditions, this product- and service differentiation is not feasible. In general, every customer receives the same quality of electricity in terms of voltage, frequency and security of supply. ${ }^{42}$ Yet, efficiency gains and economic profits might be realised if product differentiation were technically possible. ${ }^{43}$ 
There are also some interesting technical developments that demand another technological practice. There are innovative technologies that allow the production of electricity even at the level of private households. It is expected that within a few years, it will become economic to produce 'in-home electricity' to meet at least part of the need. Also, ICT and power electronics allow for opportunities of dedicated electricity supply according to the needs and preferences of individual customers. If this technical development breaks through, a new technical paradigm will occur that would fundamentally change the technological practice of this sector. This would allow for a technical decomposition (i.e. fragmentation) of the electricity system. Obviously, this technological practice would fit much better to the institutional framework of a liberalised market.

\subsection{The co-evolution between institutions and technological practises in the electricity sector}

The previous section illustrated that the liberalisation of the electricity sector resulted in an imbalance between institutions and technological practice. The issue of incoherence between institutional change and the technological status quo has been largely neglected during the process of restructuring this sector. It was implicitly assumed that the inherited technical system would adapt autonomously, according to the newly emerging incentives of competitive markets. The abovementioned examples illustrate that these assumptions do not hold in reality. The fundamental problem of the restructuring process is therefore whether a new equilibrium between institutions and technological practice can be expected and whether this is in line with the initial ideas of liberalisation.

The work of North (1990) is very helpful in dealing with this question. North (1990) extended the ideas of David (1985) and Arthur (1988) on technological 
change to institutional change. ${ }^{44}$ Thus, his framework can be applied to our fourlevel model. North argues that technological as well as institutional change are influenced by four self-reinforcing mechanisms: '(1) large setup or fixed costs, which give the advantage of falling unit costs as output increases; (2) learning effects, which improve products or lower their costs as their prevalence increases; (3) coordination effects, which confer advantages to cooperation with other economic agents taking similar action; and (4) adaptive expectations, where increased prevalence enhances beliefs of further prevalence'. ${ }^{45}$ The consequences for the evolution of these systems are characterised by four properties: '(1) multiple equilibria - a number of solutions are possible and the outcome is indeterminate; (2) possible inefficiencies - a technology that is inherently better than another loses out because of bad luck in gaining adherence; (3) lock-in - once reached, a solution is difficult to exit from; (4) path dependence - the occurrence of small events and chance circumstances can determine solutions that, once they prevail, lead one to a particular path'. ${ }^{46}$

Obviously, the institutional framework of the electricity sector has evolved into a new path of liberalisation, whereas the technological practice is still locked into the traditional trajectory. In general, two possible developments might occur.

- Dominance of the strong technological path dependence and lock-in effects. The institutions appear to be inferior against the technological practice. Institutions need to readjust to the technical conditions of this sector. This results in a stronger centralistic institutional framework that allows and supports an integrated system approach. The concrete institutional arrangements might be manifold: based on contracts, vertically integrated firms or publicly managed firms. Some recent developments in continental Europe in 
this sector towards a close oligopolistic market structure with integrated firms might fit with this development. ${ }^{47}$

- Stimulation of technological innovation that allows for a technical disintegration of the electricity system. Under these circumstances, the novel institutional framework provides sufficient incentives for innovation in technological practice. There are interesting developments in this direction, including the above mentioned opportunities for small-scale electricity production and improvements in the fields of ICT and power electronics. It can also be argued that there are important learning effects from other infrastructural sectors with the development of decentralised systems. The telecom- and ICT sectors are clear examples in this respect. ${ }^{48}$ Under these conditions, the future electricity system might function similarly to the Internet; i.e., an interconnected system of semi-independent networks. This electricity web is an interesting alternative technological paradigm, which is quite different from the current system. In this case, technology 'follows' the changes of the institutional arrangements towards liberalisation. This inhibits other relationships within the value chain with fewer system complementarities, including local or even individual electricity supply, rather than centralised; individual optimisation rather than system optimisation; and a stronger individual responsibility for the security and reliability of energy supply. Under these conditions, the delivery of electricity is evolving towards being a commodity.

There are no a priori arguments in favour of one of these developments. It is ultimately an empirical matter as to whether the technological practice or the institutional framework proves to be more dominant. Given the present state, there are no significant arguments why one of these developments is more likely to 
prevail. Our framework, however, hopefully provides a new aspect in the discussion on the restructuring of the electricity sector. It adds to the theoretical understanding of the complexity of institutional and technological change.

\section{Conclusions}

This paper deals with the interrelations between institutional and technological change. It attempts to elaborate the nature of this co-evolution in somewhat more detail with specific levels of analysis that are exemplified in a four-level model. The issue of co-evolution of technology and institutions is illustrated for the case of the restructuring of the electricity sector. In this example, the institutional framework is changed from a public utility orientation towards a new paradigm of a market-oriented system. However, the technological paradigm remained unchanged: a system-oriented approach that relies on centralised planning, control and operation. This discrepancy between institutions and technological practice leads to significant frictions of the technical functioning of the electricity sector. Some recent blackouts are just one example.

A four-level model is developed that identifies various features of institutions and technological practice and relates them to each other. For the electricity sector, two elucidatory institutional frameworks are discussed, i.e., the public utility model that represents the situation prior to the liberalisation, and the commodity model after the restructuring. The possible evolutionary developments depend on the occurrence of path dependence and lock-in effect in either the institutions or the technological practice. In a new equilibrium, either the present institutions or technology can prove to be dominant. Liberalisation can prove to be a sustainable restructuring of the electricity sector only if the technological practice applies a completely new paradigm that allows for a technological decomposition of the 
system and a more decentralised structure of technical planning and control. Current technological developments support this system change. In the case of a dominant technological path dependency, there are strong incentives to readjust the current institutional settings towards structure that supports more centralised and system-oriented behaviour. This essentially means a return to traditional forms of electricity sector organisation. Even this development cannot be excluded.

For the empirical case of the electricity sector, this paper provides new insights into the complexity of the restructuring process. In order to make liberalisation a success, it might be necessary to stimulate certain technical developments. This aspect of technology regulation has not been very well acknowledged until now in the liberalisation debate. If there is a strong political desire to let liberalisation succeed, this article suggests that regulation should stimulate certain technologies, so as to allow the development of a technological, decentralised and fragmented electricity system. The political risk is, however, quite high, given the fact that there is no experience yet with such electricity systems. The minimum requirement might therefore be that these technologies should at least not be hindered by the current regulatory framework. But again, there might be trade-offs with respect to the (joint-) functioning and performance of these different systems that cannot be resolved. Risk-adverse regulation will than prefer to retain the existing system as it is. More powerful market-driven incentives might be needed to make this transition, as stated by Perez. ${ }^{49}$

From a theoretical perspective, the article attempts to further specify the nature of the co-evolution between technology and institutions. The extension of the Williamson model (1998) from institutions towards technological practice provides an innovative view on the logic of institutional and technological change. It is now possible to define an equilibrium between both and to identify major disturbances. 
This provides some new insights into the dynamics of change in the ongoing process of liberalisation of the electricity infrastructure.

However, since the framework presented in this article is heuristic by nature, there is ample opportunity to further specify the approach. ${ }^{50}$ There are at least five quite obvious routes for further research. First, the causal relations between technological and institutional changes should be formalized more clearly, trying to put in evidence all the possible interrelations between the two dimensions and possibly being documented more precisely with some examples and if possible with data. Second, it might be tempting to extend the analysis to the entire history of the electricity sector (in particular to the origins of the network) and not only concentrate on the last time period. Applying the conceptual framework to the whole life span of the electricity network would strengthen the importance of considering the interplay between institutional and technological factors in explaining the evolution of a sector. Thirdly, a comparison between different countries could reveal national drivers for institutional and technological change in the electricity sector. Fourth, this framework can also be applied to other infrastructures and industries. Are there comparable relations and evolutionary processes? ${ }^{51}$ Last but not least it would be interesting to further explore the possible relation between the degree of (in-) coherence and dynamic efficiency. It would have to be explored under which conditions incoherence fosters technological or institutional change and innovation. Hopefully this article inspires some of these lines of research. 


\section{Literature}

Abu-Sharkh, S., Arnold, R.J., Kohler, J., Li, R., Markvart, T., Ross, J.N., Steemers, K., Wilson, P., Yao, R. (2006), 'Can Microgrids Make a Major Contribution to UK Energy Supply?' Renewable and Sustainable Energy Reviews, 10, 78-127.

Alchian, A.A., Demsetz, H. (1972), 'Production, Information Costs, and Economic Organization', in: Furubotn, E., Pejovich, S. (Eds.), The Economics of Property Rights, Cambridge (Massachusetts).

Arentsen, M.J., Künneke, R.W. (2003), 'National Models in the Emerging European Gas Market', in: Arentsen, M.J., Künneke, R.W. (Eds.), National Reforms in European Gas, Elsevier Science, Oxford, pp. 45-61.

Arthur, B.W. (1988), 'Competing Technologies: An Overview', in: Dosi, G., Freeman, C., Nelson, R.R., Silverberg, G., Soete, L. (Eds.), Technical Change and Economic Theory, Pinter, London.

Casten, T.R. (1990), 'Whither Electric Generation? A Different View', The Energy Daily, www.theenergydaily.com.

Commons, J.R. (1934), 'Institutional Economics: Its Place in Political Economy', New York.

David, P.A. (1985), 'Clio and the Economics of QWERTY', American Economic Review, 75, 332-337. 
De Alessi, L. (1980), 'The Economics of Property Rights: A Review of the Evidence', Research in Law and Economics, 2, 1-47.

Denzau, A.T., North, D.C. (1994), 'Shared Mental Models; Ideologies and Institutions', Kyklos, 47.

Dixit, A. (1996), 'The Making of Economic Policy: A Transaction Cost Politics Perspective', MIT Press, Cambridge.

Dosi, G. (1982), 'Technological Paradigms and Technological Trajectories: A Suggested Interpretation of the Determinants and Directions of Technical Change', Research Policy, 11, 147-162.

Eggertsson, T. (1990), 'Economic Behavior and Institutions', Cambridge.

Electric Power Research Institute (EPRI) (2006), Annual Report: Together... Shaping the Future of Electricity, San Francisco, www.epri.com

en.wikipedia.org (2007), List of power outages - Wikipedia, the free encyclopedia, http://en.wikipedia.org/wiki/List of power outages

Enslin, J.H.R., Heskes, P.J.M. (2004), 'Harmonic interaction between a large number of distributed power inverters and the distribution network,' IEEE Transactions on Power Electronics, 19, 1586-1593.

European Commission (2006), European Smart Grids Technology Platform: Vision and Strategy for Europe's Electricity Networks of the Future, Luxemburg, Directorate-General for Research, www.smartgrids.eu 
Fama, E.F. (1980), 'Agency Problems and the Theory of the Firm', Journal of Political Economics, 88.

Fama, E.F., Jensen, M.C. (1983), 'Separation of Ownership and Control', Journal of Law and Economics, 26.

Fens, T. (Ed.) (2005), Trends in Energy: Utility Value Chain Optimization, Cap Gemini, Utrecht.

Finger, M., Groenewegen, J.P.M., Künneke, R.W. (2005), 'The Quest for Coherence Between Technology and Institutions in Infrastructures', Journal of Network Industries, 6, 227-259.

Furubotn, E., Pejovich, S. (Eds.) (1974), The Economics of Property Rights, Cambridge (Massachusetts).

Galbraith, J.K. (1968), 'The New Industrial State', 2nd ed, Houghton Mifflin Co, Boston.

Granovetter, M. (1985), 'Economic Action and Social Structure: The Problem of Embeddedness', American Journal of Sociology, 91.

Groenewegen, J.P.M., Künneke, R.W. (2005), 'Process and Outcomes of the Infrastructure Reform: An Evolutionary Perspective ', in: Künneke, R.W., Correlje, A.F., Groenewegen, J.P.M. (Eds.), Institutional Reform, Regulation, and Privatization, Edward Elgar, Cheltenham. 
Hodgson, G.M. (2000), 'What is the Essence of Institutional Economics?' Journal of Economic Issues, 34, 317-329.

Holmstrom, B. (1979), 'Moral Hazard and Observability', Bell Journal of Economics, 10, 74-91.

Holmstrom, B., Milgrom, P. (1991), 'Multi-task Principal-Agent Analysis', Economics, and Organization, 7, 24-52.

Hunt, S., Shuttleworth, G. (1996), 'Competition and Regulation in Electricity', John Wiley \& Sons, Chichester.

Joskow, P.L., Schmalensee, R. (1983), 'Markets for Power: An Analysis of Electric Power Deregulation', MIT Press.

Künneke, R.W., Fens, T. (2007), 'Ownership Unbundling in Electricity Distribution: The case of The Netherlands', Energy Policy, 35, 1920-1930.

Künneke, R.W., Finger, M. (2007), 'Technology Matters: The Cases of the Liberalization of Electricity and Railways', Competition and Regulation in Network Industries, 8, 301-334.

Libecap, G.D. (1986), 'Property Rights in Economic History: Implications for Research', Explorations in Economic History, 23, 227-252.

Matthes, F.C., Grashof, K., Gores, S. (2007), Power Generation Market Concentration in Europe 1996-2005. An Empirical Analysis, Berlin, Öko-Institut e.V., www.oeko.de 
Nelson, R.R., Sampat, B.N. (2001), 'Making Sense of Institutions as a Factor Shaping Economic Performance', Journal of Economic Behavior \& Organization, 44, 31-54.

Nelson, R.R., Winter, S.G. (1982), 'An Evolutionary Theory of Economic Change', Cambridge (Massachusetts).

Nightingale, P., Brady, T., Davis, A., Hall, J. (2003), 'Capacity Utilization Revisited: Software, Control, and the Growth of Large Technical Systems', Industrial and Corporate Change, 12, 477-517.

Nooteboom, B. (1993), 'Networks and Transactions: Do They Connect?' in: Groenewegen, J.P.M. (Ed.), The Dynamics of the Firm, Edward Elgar, Aldershot.

North, D.C. (1990), 'Institutions, Institutional Change, and Economic Performance', Cambridge University Press, Cambridge (Mass).

Perez, C. (2002), 'Technological Revolutions and Financial Capital: The Dynamics of Bubbles and Golden Ages', Edward Elgar, Cheltenham, UK.

Saviotti, P.P. (1996), 'Technological Evolution, Variety, and the Economy', Edward Elgar, Cheltenham.

Soete, L. (1985), 'International Diffusion of Technology, Industrial Development and Technical Leapfrogging', World Development, 13, 402-422.

standards.nerc.net (2007), Standards Home, https://standards.nerc.net/ 
Thomas, S. (2003), 'The Seven Brothers', Energy Policy, 31, 393-403.

Veblen, T. (1919), 'The Vested Interests and the Common Man', New York.

Von Tunzelmann, N. (2003), 'Historical Coevolution of Governance and Technology in the Industrial Revolutions', Structural Change and Economic Dynamics, 14, 365-384.

Williamson, O.E. (1985), 'The Economic Institutions of Capitalism', The Free Press, New York, London.

Williamson, O.E. (1998), 'Transaction Cost Economics: How It Works, Where It Is Headed', De Economist, 146, 23-58.

Winter, S.G. (2000), 'The Satisficing Principle in Capability Learning', Strategic Management Journal, 21, 981-996.

www.gridwise.org (2007), GridWise.org, http://www.gridwise.org/

www.smartgrids.eu (2007), SmartGrids: European Technology Platform, http://www.smartgrids.eu 
${ }^{1}$ Thanks to John Groenewegen, Laurens de Vries (both Delft University of Technology), Claude Menard (University of Paris 1), Giovanni Dosi (Santa Anna School of Advanced Studies, Pisa) and two anonymous referees for their very helpful comments on earlier versions of this paper. Deborah Sherwood provided assistance in language editing of the manuscript.

${ }^{2}$ Joskow and Schmalensee (1983).

${ }^{3}$ www.smartgrids.eu (2007). This program stresses the need for technological innovations in electricity networks. Electricity networks need to become more active, intelligent and decentralized in order to meet future challenges like sustainability, reliability and the changing incentives of liberalized markets. However, there is no blueprint about the technical and institutional features and characteristics of these future networks. The EU program aims to bring together all the stakeholders in order to elaborate the opportunities for technological and institutional change. "For a successful transition to a future sustainable energy system all the relevant stakeholders must become involved: governments, regulators, consumers, generators, traders, power exchanges, transmission companies, distribution companies, power equipment manufactures and ICT providers. There is a strong need for pilot projects, not only in the technical sense but also at the markets and organisational level. For example, regulatory regimes should be revised, based on new knowledge about how regulation should work to provide incentives for innovation. New organisational structures can be implemented and monitored for the benefit of all parties, for example allowing network companies to conduct limited commercial activities with respect to long time investments.” Cited from European Commission (2006), p.13.

${ }^{4}$ Electric Power Research Institute (EPRI) (2006), p.6. More detailed information is available on the EPRI website (www.epri.com). Refer also to note 43.

${ }^{5}$ www.gridwise.org (2007)

${ }^{6}$ The recent publications of Abu-Sharkh et al. (2006) and Enslin and Heskes (2004) serve as illustrative examples for the regulatory and technological challenges in this field. 
${ }^{7}$ In addition to completely integrated firms as shown in Figure 1, partial integration was also quite common. In this case there were two different kinds of integration: production, trade and transmission, in addition to distribution, metering and sales.

${ }^{8}$ Different models of electricity sector restructuring are discussed in Hunt and Shuttleworth (1996), Chapter 3. Using the traditional model of the regulated monopoly as a point of reference, there are three basic opportunities for restructuring, i.e., the establishment of a purchasing agency, wholesale competition and retail competition. The main differences between these models are related to the degree of unbundling of the value chain. In the case of a purchasing agency, there is only competition in generation. A single buyer (i.e., the purchasing agency) aggregates the production capacity, while the remainder of the sector is still monopolistic. Allowing wholesale competition enables competition between generators and choice for retailers. Thus, there is competition in the upstream part of the electricity sector. In addition to this model, retail competition even allows choice for the final customers at the downstream part of the sector.

${ }^{9}$ There are, for instance, different regulatory requirements with respect to the unbundling of commercial and regulated activities in the electricity sector. Some countries might require complete ownership unbundling between the network companies and commercial electricity firms. In other cases, only administrative unbundling might be obligatory. In the EU, there is presently a heated discussion on the need and desirability of complete ownership unbundling for all electricity networks. It is argued that competitive electricity markets can only develop on a European scale if the networks are completely independent from the commercial activities of the energy firms.

${ }^{10}$ Joskow and Schmalensee (1983), p.45-54.

${ }^{11}$ Hunt and Shuttleworth (1996), p.2. This graph is from Casten (1990)

${ }^{12}$ The technical quality of electricity depends on, among others, a constant voltage (240 V or $110 \mathrm{~V}$ ) and frequency (50 or $60 \mathrm{Hertz}$ ). The more stable these technical parameters, the higher the quality of electricity supply.

${ }^{13}$ This paragraph builds on Groenewegen and Künneke (2005)

${ }^{14}$ Williamson (1998), p. 27. 
${ }^{15}$ Recent contributions in this field are from Denzau and North (1994), Galbraith (1968), Granovetter (1985), Hodgson (2000), Nelson and Winter (1982), and Nooteboom (1993).

${ }^{16}$ Contributors include: Alchian and Demsetz (1972), Furubotn and Pejovich (1974), Libecap (1986), De Alessi (1980), and Eggertsson (1990).

${ }^{17}$ Williamson (1985), Fama and Jensen (1983), Fama (1980).

${ }^{18}$ Together with the theory of property rights of Level 2, they form the New Institutional Economics (NIE).

${ }^{19}$ Williamson (1998), p.29.

${ }^{20}$ This is the so called normative branch of agency theory. Williamson (1998), p. 29, refers to the work of Holmstrom (1979), Holmstrom and Milgrom (1991) and Dixit (1996).

${ }^{21}$ Williamson (1998), p.26

${ }^{22}$ Künneke and Fens (2007)

${ }^{23}$ This is the case of price cap regulation. The prices are calculated according to the following formula: $\mathrm{p}(\mathrm{t}+1)=\mathrm{P}(\mathrm{t})(\mathrm{RPI}-\mathrm{x}+\mathrm{q})$ with $\mathrm{p}$ : the price in $\mathrm{t}$ or $\mathrm{t}+1$, RPI: retail price index, $\mathrm{x}$ : the increase of productivity, q: quality parameter such as outage of electricity supply.

${ }^{24}$ Of course, there are also more hybrid models of liberalisation. Profits of network operators might be restricted by, for instance, rate of return regulation. Electricity firms engaged in production trade and supply might be owned by public entities, while operating in competitive markets. Public ownership of network companies is still quite common.

${ }^{25}$ With respect to institutional arrangements, this question is addressed by Groenewegen and Künneke (2005).

${ }^{26}$ Examples for the optimisation of technical routines include the Fordist type of assembly line organisation of production processes.

${ }^{27}$ Dosi (1982), p. 158. It should be stressed that the differentiation between paradigms and trajectories is rather heuristic and should not be interpreted too deterministically. In Dosi's words, "the analogy between science and technology is, in some respects, 'impressionistic', and the parallel should not be pushed too far without reaching decreasing returns”. In reality, for instance, it is not always straightforward to draw a clear line between paradigms and trajectories. This also holds for the frequency of change. However, as will be argued 
further on, there is some interesting empirical evidence that seems to support our line of reasoning and helps in understanding the nature of the co-evolution between technologies and institutions.

${ }^{28}$ Von Tunzelmann (2003), p.371.

${ }^{29}$ Perez (2002), p. 10-11.

${ }^{30}$ Saviotti (1996), p.96, refers to different cases of incremental and radical change.

${ }^{31}$ Changes of the technological paradigm might occur in some sectors only very rarely, sometimes only over a period of decennia. The electricity sector that is discussed in this paper is a good example. The large-scale, centralized system of production and transport of electricity emerged at the beginning of the $20^{\text {th }}$ century, some hundred years ago. Still this is the dominant paradigm for the provision of electric power. Other examples for very long lasting technological paradigms in infrastructure industries include the provision of drinking water, sewer systems, and the inland shipping water ways. .

${ }^{32}$ Interesting empirical examples are provided in Nightingale et al. (2003). For instance in the telecom sector, the lack of network capacity proved to be an important driver for the shift from a centralized towards decentralized telecom networks.

${ }^{33}$ Dosi (1982)

${ }^{34}$ Finger et al. (2005), p.242-243

${ }^{35}$ Central dispatch refers to the utilisation of the various production plants in a merit order in accordance to their unit price of production.

${ }^{36}$ The total amount of the necessary reserve capacity declines for a given security of supply.

${ }^{37}$ Dosi (1982)

${ }^{38}$ For illustration of these network codes, refer to: standards.nerc.net (2007), the standards defined by the North American Reliability Cooperation (NERC). This is a self- regulating body of North American network companies.

${ }^{39}$ Arentsen and Künneke (2003)

${ }^{40}$ Künneke and Finger (2007) elaborate this aspect more in detail.

${ }^{41}$ For an extensive list of wide scale power outages, refer to en.wikipedia.org (2007). These power outages are caused by various circumstances, including extreme climatic conditions, 
external forces like falling trees, and technical malfunctions. A recent example of a technical system failure in Europe is the power outage of November $4^{\text {th }}, 2006$, which affected some 5 million people in Germany, France, Italy, Belgium and Portugal. There is an ongoing discussion on the vulnerability of the electricity network, and how to improve its protection through technical and regulatory means.

${ }^{42}$ Large industrial customers are the exemption to this case, as far as security of supply is concerned. These customers are typically connected to the high voltage grid with individual monitoring and metering devices. These customers can opt for interruptible contracts. They might be disconnected in the case of scarcity of electricity supply. This type of product differentiation is quite common in the electricity sector for large industrial users.

${ }^{43}$ This kind of product differentiation mainly depends on the technical possibilities offered by distribution networks to allow for a dedicated delivery of electricity on the level of individual customers. This requires the development of so called 'smart grids', which are a completely new technological concept (refer to endnotes 3, 4, and 5). One of the institutional-economic problems is the absence of clear incentives to invest in these networks under current conditions. Under the current regulatory conditions in liberalised markets, this would be the task of the distribution network companies. These companies are strictly regulated, and there are insufficient mechanisms to financially reward these firms if they start to experiment with these novel technological concepts. Only in the UK was there a regulatory system introduced that offers higher regulated returns for these kinds of technological experiments in so-called 'registered power zones'.

${ }^{44}$ North (1990), p. 92 pp.

${ }^{45}$ North (1990), p. 94.

${ }^{46}$ North (1990), p.94

${ }^{47}$ This process of concentration in the electricity sector is described in an early article by Thomas (2003). A recent study of Matthes et al. (2007) revealed different development patterns. The UK and Scandinavian markets can be described as quite competitive and unconcentrated, while the markets in continental Europe are clearly dominated by a few big firms. Because of the physical restrictions of insufficient cable capacity, especially with respect to interconnections between different countries, electricity markets have a 
dominantly regional scope with only limited opportunities for international exchange. Moreover, long-distance transport of electricity suffers from line losses, which makes this only efficient on shorter distances of a few hundreds of kilometers.

${ }^{48}$ Nightingale et al. (2003) demonstrate the changing nature of the control mechanism of the telecom infrastructure.

${ }^{49}$ Perez (2002), pp.10-11.

${ }^{50}$ I am thankful to an anonymous referee for making me aware of some of these possible lines for future research.

${ }^{51}$ A first attempt is made by Finger et al. (2005) and Künneke and Finger (2007). 